\title{
The Application of Hospital Safety Index for Analyzing Primary Healthcare Center (PHC) Disaster and Emergency Preparedness
}

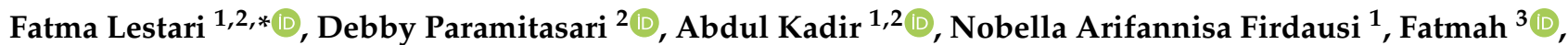 \\ Achir Yani Hamid ${ }^{4}$, Suparni ${ }^{5}$, Herlina J. EL-Matury ${ }^{6}$, Oktomi Wijaya ${ }^{7}$ and Avinia Ismiyati ${ }^{8}$
}

1 Occupational Health and Safety Department, Faculty of Public Health, Universitas Indonesia, Depok 16424, Indonesia; abdul_kadir@ui.ac.id (A.K.); nobellaarifannisa@gmail.com (N.A.F.)

2 Disaster Risk Reduction Centre (DRRC), Universitas Indonesia, Depok 16424, Indonesia; debbyparamitasari@gmail.com

3 Disaster Management Study Program, School of Environmental Science, Universitas Indonesia, Salemba, Jakarta 10430, Indonesia; ffatmah@yahoo.com

4 Faculty of Nursing, Universitas Indonesia, Depok 16424, Indonesia; achir@ui.id

5 Department of Public Health, STIKes Dharma Husada Bandung, Bandung 40282, Indonesia; nsurparni@stikesdhb.ac.id

6 Faculty of Public Health, Institute of Health Deli Husada Deli Tua, Deli Serdang 20355, Indonesia; herlinajelmatury.hjem@gmail.com

7 Faculty of Public Health, Universitas Ahmad Dahlan, Yogyakarta 55164, Indonesia; oktomi.wijaya@ikm.uad.ac.id

8 Jakarta Occupational Health and Safety Technical Service Unit, Ministry of Manpower, Jakarta 10510, Indonesia; avinia.ismiyati@kemnaker.go.id

* Correspondence: fatma@ui.ac.id

\section{check for} updates

Citation: Lestari, F.; Paramitasari, D.; Kadir, A.; Firdausi, N.A.; Fatmah; Yani Hamid, A.; Suparni; EL-Matury, H.J.; Wijaya, O.; Ismiyati, A. The Application of Hospital Safety Index for Analyzing Primary Healthcare Center (PHC) Disaster and Emergency Preparedness. Sustainability 2022, 14, 1488. https://doi.org/10.3390/su14031488 Academic Editor: Hing-Ho Tsang

Received: 14 December 2021 Accepted: 23 January 2022 Published: 27 January 2022 Publisher's Note: MDPI stays neutral with regard to jurisdictional claims in published maps and institutional affiliations.

Copyright: (C) 2022 by the authors. Licensee MDPI, Basel, Switzerland. This article is an open access article distributed under the terms and conditions of the Creative Commons Attribution (CC BY) license (https:// creativecommons.org/licenses/by/ $4.0 /)$.

\begin{abstract}
The World Health Organization (WHO) defines the primary healthcare center (PHC) as a whole-of-society approach to health that aims at ensuring the highest possible level of health and well-being and their equitable distribution by focusing on people's needs as early as possible along the continuum from health promotion and disease prevention to treatment, rehabilitation, and palliative care, and as close as feasibly possible to people's everyday environment. PHCs are expected to remain operational when disasters occur. This study aimed to assess the PHC disaster preparedness level in Indonesia using The Hospital Safety Index (HSI) from WHO/PAHO. Eleven PHCs located in four provinces in Indonesia, i.e., Jakarta, Yogyakarta, North Sumatera, and West Java, were selected. Data were collected through interviews, focus-group discussions (FGDs), observations, and document reviews. The parameters assessed were all types of hazards, structural or construction safety, nonstructural safety, and functional attributes. The results show that the overall score of HSI for PHCs in Jakarta (0.674) and North Sumatera (0.752) fell into the "A" category, meaning that these PHCs would likely remain operational in the case of disasters. Meanwhile, the overall HSI scores for PHCs in West Java (0.601) and Yogyakarta (0.602) were between 0.36 and 0.65, or in " $\mathrm{B}$ " category, meaning that these PHCs would be able to recover during disasters but several services would be exposed to danger. The results suggested that there are several gaps that need urgent interventions to be applied for the structural safety of buildings, water supply systems, fuel storage, disaster committee organization, furniture and fittings, offices and storage equipment, as well as increasing the capacity of workers through a structured and systematic training framework for disaster readiness. The results from this study can be used for prioritizing budgets and resource allocation, cost planning, providing specific solutions for local and national government, and efforts to achieve disaster risk reduction.
\end{abstract}

Keywords: disaster risk reduction; hospital safety index; disaster preparedness primary healthcare 


\section{Introduction}

Protecting the lives of people affected by a disaster or emergency immediately after the event strikes is essential; this involves health services, including those provided by primary healthcare centers (PHCs). PHC is a healthcare service facility that organizes the public health approach and first-level individual health efforts by prioritizing promotive and preventive actions in its working area [1]. It must be accessible and well-functioning in this situation as it might become the determining factor of survival because the health system plays a major role in the mitigation and responses to disasters and emergencies, including during the currently ongoing COVID-19 pandemic [2-4]. Scholars focusing on public health preparedness from around the world have been concerned about the state of PHC disaster readiness for more than three decades $[5,6]$. The World Health Assembly held in 1981 pointed out the importance of preventive measures and preparedness, along with relief in emergencies. A decade later, the International Decade for Natural Disaster Reduction (IDNDR) stressed the fundamentals of health sector preparedness. The idea is then pursued in the Hyogo Framework for Action (2005-2015) and Sendai Framework for Disaster Risk Reduction (2015-2030) by promoting hospital and primary healthcare facility resilience to ensure that said facilities are safe, effective, and functioning before and after disaster events [7,8]. Furthermore, the Declaration of Astana, as declared by the global health community in Astana, Kazakhstan in 2018, emphasizes three components of PHC, including multisectoral policy and action, people and community empowerment, and integrated health services of primary care and other essential public health functions [9].

Healthcare facilities play an important role during disaster situation in order to save lives and providing healthcare services for the communities impacted by disasters. Healthcare facilities are expected to stay fully functional during and immediately after the disaster strikes. Therefore, it is highly important to conduct an evaluation of PHCs' emergency and disaster preparedness. There are several elements that can be used to evaluate the emergency and disaster preparedness in healthcare facilities [10]. Mojtahedi et al. (2021) [10] evaluate disaster preparedness by assessing the emergency and disaster management coordination, response and disaster recovery planning, communication and information management, logistics and evacuation, human resources, finance, patient care and support services, decontamination, and security. Yazdani et al. (2021) [11] focus on evaluating the disaster readiness on planning and patient evacuation. On the other hand, Aghapour (2019) [12] highlights the importance of expanding the hospital's room, increasing surge capacity for disaster management.

Indonesia, a country composed of hundreds of islands, is located on three tectonic plates known as the Indo-Australia, Eurasia, and Pacific plates [13]. The movements of these tectonic plates have formed volcanoes (Indonesia has more than 160 active volcanoes) and faults across the Indonesian islands, whose activities bring a high probability of disaster events, particularly earthquakes, tsunamis, volcanic eruptions, and landslides [13]. In 2020, 2939 disasters occurred in Indonesia, causing 370 deaths, 39 people reported missing, 536 injured, and 6.4 million displaced. In addition, the disasters damaged various critical facilities, including 143 health facilities [14,15]. In two recent large disasters, Lombok earthquakes (2018) and the earthquakes, tsunamis, and liquefaction in Palu and Donggala, numerous health facilities were also affected (2018). In the Lombok earthquakes, 156 PHCs and two hospitals were damaged with damages ranging between minor, medium, and severe [16]. In addition, the earthquakes, tsunamis, and liquefactions in Palu and Donggala in 2018 damaged 167 PHCs facilities and 18 hospitals [17].

Indonesia has also been severely impacted by the current ongoing COVID-19 pandemic. It has been more than a year since the President of Indonesia announced the first confirmed cases in early March 2020. As of March 10, 2021, there have been 1,398,578 confirmed cases in Indonesia, with 144,213 active cases, 1,216,433 recovered, and 37,932 dead [18]. During the pandemic, the PHCs function not only as the provider of primary health services to the community but also to implement COVID-19 precautions and COVID19-related services, where they play an essential role in COVID-19 prevention, detection, 
and responses [4,19]. The PHCs are responsible for providing support to more than $80 \%$ of COVID-19 patients who conduct self-quarantine or self-isolation at home. Simultaneously, people who are not affected by COVID-19 also require assistance to increase their awareness of COVID-19 and mitigate their risk of exposure [4]. Recently, a tragic fire incident occurred in a COVID-19 ward of the al-Hussain hospital in Southern Iraq, causing 92 fatalities and more than 100 injuries. The investigation result reported that the hospital was not prepared to face a fire incident, having a lack of fire alarms and sprinklers as well as being unprepared and having limited hospital response plans and teams [20,21].

When health facilities, specifically PHCs, which are supposed to be a place for people to rely upon during and after a disaster or pandemic, do not function well and/or are damaged due to disaster or lack of preparedness, people in the community who are injured or require health assistance will become the ones who are affected the most [22]. A safe PHC with services that are still highly accessible and well-functioning within the same structure before, during, and after a disaster or pandemic is crucial to the well-being of any community. In addition, the procedure of a seismic risk mitigation strategy is based on a global risk index involving the entire building stock under study, thus facilitating an examination of risk variation over time up to its final value [23]. In all the surveyed hospitals, there were partially or totally unusable buildings causing severe limitations to the functionality of the healthcare services, forcing to move many patients to other hospitals and to stop outpatient treatment. This was mainly due to severe damage to non-structural components and, in some cases, to moderate damage to structural components [24]. A short description of the damage suffered and characteristics of the healthcare system as a whole is offered initially, followed by a detailed description of the effects which took place at the Santa Maria Bianca hospital of Mirandola. The focus has been on damage to non-structural elements and content, whose integrity is of primary importance for the performance of healthcare structures during and after a seismic event [25]. The Pan American Health Organization (PAHO) and World Health Organization (WHO) provide a safety index as a function of all the parameters that characterize the seismic risk: vulnerability, hazard, and exposition [26].

The Hospital Safety Index (HSI) checklist has been applied to assess and ensure the safety of hospitals during disaster events. For new hospitals, the HSI is used as a benchmark of safety standards, whereas for the existing ones, the HSI is used to identify additional measures necessary to meet the required safety standards [23]. Given the diverse level, size, and function of hospitals, the level of safety is different for each hospital. Midsize and small hospitals are less complex compared to major hospitals. In the Indonesian context, the PHCs with in-patient services could be categorized as medium or small hospitals. The HSI tool for medium and small hospitals is similar to the HSI for major hospitals, consisting of items to assess vulnerabilities in the structural or construction, nonstructural, and functional attributes of the facility. The results of the evaluation can then be used as a standardized guide to build new PHCs or improve the safety of an existing facility during any emergencies or disasters [27]. Therefore, it is important to conduct a survey and analysis on the safety index of PHC facilities in Indonesia.

The assessment of hospital emergency preparedness is important in order to elucidate weaknesses in the hospital disaster plan and to guarantee effective hospital functions during disasters $[28,29]$. Assessment methods and checklists have been created by researchers and authorities [28,30-33]. However, there is no consensus on a both valid and reliable tool with which to measure hospital preparedness [29,32-34]. Moreover, most countries tend to use their own assessment tools [30-32,34]. Currently, Indonesia utilizes the Hospital Safety Index (HSI) issued by the WHO/PAHO to determine hospital preparedness for disaster, and it is also used in the assessment of hospital accreditation in the National Hospital Accreditation Standard (SNAR). The researcher believes that using a validated international tool such as HSI [23] is beneficial, allowing for standardized comparisons.

This research aims to assess the disaster readiness and preparedness level of PHCs in Indonesia using the WHO/PAHO Guidelines: Evaluation of Small \& Medium-Sized Health 
Facilities, Fourth Edition. A total of 11 PHCs, also known as "Puskesmas", in four provinces in Indonesia (Jakarta, Yogyakarta, North Sumatera, and West Java) were selected for unit analysis. Thus, our present study will address the following research questions: are PHCs in Indonesia adequately prepared for disaster? What are the levels of PHC preparedness in Indonesia? Which are the weakest/lowest variables among disaster preparedness level and readiness items? To be able to answer those questions, multidisciplinary research that integrates expertise from several disciplines including public health, nursing, environmental science, and disaster management is needed, as is implemented in this research.

\section{Materials and Methods}

\subsection{Study Location, Sampling and Data Collection}

Figure 1 presents the locations of the selected PHCs in four provinces in Indonesia for this research. During 2020, the National Disaster Management Agency (Badan Nasional Penanggulangan Bencana, BNPB) recorded a total of 2939 disaster events in Indonesia [10,11]. Daerah Khusus Ibukota (DKI) Jakarta or the Special Capital Area of Jakarta was selected for several reasons, including the fact that Jakarta is the capital city of Indonesia, with a dense population and many high-rise buildings. This city is also prone to various disasters and emergencies including floods, labor strikes, and other social phenomena. West Java is a province that is prone to earthquakes, tsunamis, landslides, and floods while Yogyakarta is prone to earthquakes, floods, tsunamis, and volcanic eruptions from Mount Merapi. North Sumatera Province was also selected because it is prone to earthquakes, floods, and tsunamis [35-39].

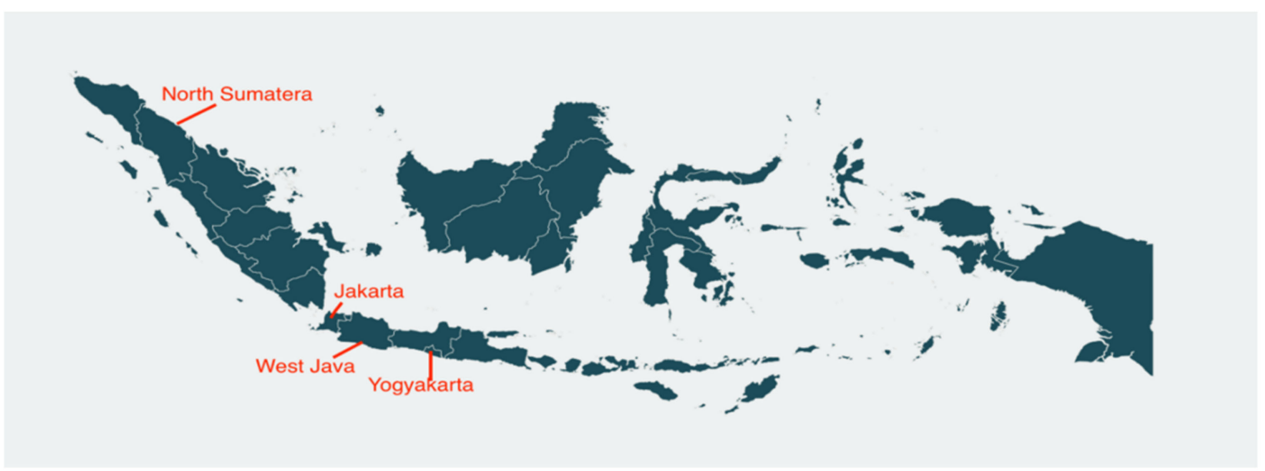

Figure 1. Selected primary healthcare facility locations.

Research conducted in 4 (four) provinces in Indonesia: North Sumatera, DKI Jakarta, West Java and Special Provinces of Yogyakarta. Samples were selected using a purposive sampling technique. PHCs were selected based on the most susceptible and vulnerable locations. Table 1 depicts the data of 11 (eleven) selected PHCs for this study:

Table 1. Information on 11 PCHs.

\begin{tabular}{ccccc}
\hline Province & PHC Name & Types of PHCs & $\begin{array}{c}\text { Number of } \\
\text { Buildings }\end{array}$ & Number of Bed \\
\hline Sumatera Utara & PHC A & $\begin{array}{c}\text { Puskesmas } \\
\text { rawat inap (PHC } \\
\text { in-care patient) } \\
\text { Puskesmas } \\
\text { rawat inap (PHC } \\
\text { in-care patient) } \\
\text { Puskesmas } \\
\text { rawat inap (PHC } \\
\text { in-care patient) }\end{array}$ & 1 & 5 \\
\hline
\end{tabular}


Table 1. Cont.

\begin{tabular}{|c|c|c|c|c|}
\hline Province & PHC Name & Types of PHCs & $\begin{array}{l}\text { Number of } \\
\text { Buildings }\end{array}$ & Number of Bed \\
\hline \multirow[t]{2}{*}{ DKI Jakarta } & PHC D & $\begin{array}{c}\text { Puskesmas } \\
\text { rawat inap (PHC } \\
\text { in-care patient) }\end{array}$ & 1 & 10 \\
\hline & PHC E & $\begin{array}{c}\text { Puskesmas } \\
\text { rawat inap (PHC } \\
\text { in-care patient) }\end{array}$ & 1 & 10 \\
\hline \multirow[t]{3}{*}{ Jawa Barat } & PHC F & $\begin{array}{c}\text { Puskesmas } \\
\text { rawat inap (PHC } \\
\text { in-care patient) } \\
\text { Puskesmas }\end{array}$ & 2 & 15 \\
\hline & PHC G & $\begin{array}{l}\text { rawat inap (PHC } \\
\text { in-care patient) }\end{array}$ & 5 & 23 \\
\hline & PHC H & $\begin{array}{c}\text { Puskesmas } \\
\text { rawat inap (PHC } \\
\text { in-care patient) }\end{array}$ & 2 & 22 \\
\hline \multirow[t]{3}{*}{$\begin{array}{c}\text { Daerah Istimewa } \\
\text { Yogyakarta }\end{array}$} & PHC I & $\begin{array}{c}\text { Puskesmas } \\
\text { rawat inap (PHC } \\
\text { in-care patient) }\end{array}$ & 2 & 10 \\
\hline & PHC J & $\begin{array}{c}\text { Puskesmas non } \\
\text { rawat inap (PHC } \\
\text { outpatient } \\
\text { services) }\end{array}$ & 1 & - \\
\hline & PHC K & $\begin{array}{c}\text { Puskesmas non } \\
\text { rawat inap (PHC } \\
\text { outpatient } \\
\text { services) }\end{array}$ & 1 & - \\
\hline
\end{tabular}

The sampling method applied in this study is the non-probabilistic purposive sampling. The PHCs were chosen based on the analysis of study objectives as well as the agreement with local health authorities. Eleven (11) PHCs participated in the study: two (2) were in Jakarta (capital city of Indonesia), three (3) in West Java, three (3) in Yogyakarta, and three (3) in North Sumatera.

HSI recommends using a combined method of data collection: document reviews, in-depth interviews, focus group discussions, and systematic observations [23]. Data collection was performed by a group of four surveyors and evaluators, including a disaster management expert, a nurse, a public health officer, and a civil engineer, all experts in hospital disaster management. Data were collected in four months because the surveyors and evaluators needed at least four days to collect data from a PHC during this extreme pandemic situation, as well as due to the complexity of the HSI data collection. An information session was held with each PHC to inform about the research. Furthermore, in-depth structured interviews were then conducted with selected key informants from each PHC that could answer questions about potential hazards and disaster risks, as well as structural and nonstructural aspects of HSI. After that, observations on the PHCs were conducted through offline and virtual video conference. Focus-group discussion (FGD) that involved the PHC heads, administrative personnel, emergency responders, building services and electrical maintenance personnel, and public health officers was also conducted to gather the group perspective on the HSI condition in the facilities. Additionally, a document review was performed to review the existing measurements. The quantitative data collection was conducted to determine the PHC disaster preparedness level using the WHO/PAHO Guidelines: Evaluation of Small \& Medium-Sized Health Facilities, Fourth edition (2015) [23]. 


\subsection{Hospital Safety Index for Evaluation of Small and Medium-Sized Health Facilties}

The level of PHC disaster preparedness was assessed using the Hospital Safety Index (HSI) WHO/PAHO Guidelines: Evaluation of Small \& Medium-Sized Health Facilities, Fourth Edition, which includes several modules, i.e., geographical (22 items), structural (14 item), nonstructural (47 items), and functional (33 items) modules, with a total of 166 items. The following provide more detailed information of the four modules [23].

\subsubsection{Module 1: Potential Hazards and Disaster Risks}

This section refers to the issues of the geographic location of a primary healthcare (PHC) facility, which could help in identifying potential disaster hazards and risks surrounding the health facilities, as well as geotechnical properties.

a. Hazards mean some type of potential disaster that may occur, such as geological, social, hydro-meteorological, technology, environmental health, and geotechnical disasters.

b. Geotechnical properties of soil cover general aspects of soil mechanics and geotechnical properties of soil as they relate to structural problems in hospitals.

\subsubsection{Module 2: Structural Aspects}

Module 2 discusses the structural elements of the facilities, consisting of foundations, columns, beams, walls, roof frames, etc. that support the structure and construction, involving the safety level related to the hospital histories and building integrity.

a. Safety level related to hospital histories: assesses by finding the history of the PHC, such as prior major structural damage of failure, built and/or refurbished using existing safety standards, and structural behavior.

b. Building integrity which focuses on the building condition, interaction of nonstructural elements, materials construction, building proximity, redundancy, structural detailing, irregularities, integrity of roofs, safety of foundations, and structural resilience to hazards.

\subsubsection{Module 3: Nonstructural Aspects}

Modul 3 refers to the elements that do not construct part of the load-bearing structure of the health facility. These components may or may not be attached to the load-bearing structure and include architectural elements (for example, partition walls, facades, windows, doors, ceilings, etc.)

a. Lifelines include the electrical systems, lighting systems, emergency maintenance systems, telecommunication systems, alternate communications systems, water supply systems, location of water storage tanks, water quality control, fuel storage, and sanitation systems.

b. Heating, ventilation, air conditioning (HVAC), and/or hot water, mainly in critical areas such as the condition of safety HVAC components.

c. Furniture and fittings, office, and storage equipment includes safety of cupboard and its contents, safety of office equipment, protection of furniture, protection of furniture and fittings, and protection of warehouse and storage.

d. Medical and laboratory equipment and supplies used for diagnosis and treatment, particularly the protection of medical and laboratory equipment.

e. Architectural components: safety and condition of doors, exits and entrances, windows and shutters, building envelope, roofing, parapets, and other outside elements, movement outside the building, etc.

\subsubsection{Module 4: Functional Aspects}

Module 4 assesses the general organization of the hospital's authorities, implementation of plans and programs, availability of resources, the level of development and readiness of its personnel, and safety level of the priority services needed for the facility to 
remain function. The functional aspect consists of systems that integrate human, material, economic, and technological aspects to function well in providing health services.

a. Organization of the primary healthcare's disaster committee: evaluation of the primary healthcare facility's level of organization for responding to disasters begins with an assessment of the disaster committee.

b. Primary healthcare emergency or disaster response plan: evaluation of the primary healthcare facility's operational planning for internal and external emergency and disaster events.

c. Availability of medications, supplies, instruments, equipment for disaster situations: cross-checks the list of available supplies with those that are essential in emergencies.

\subsection{Data Analysis, Weighting, and Score Calculation}

Two different data analysis methods were applied in this study. First, the overall score of HSI was calculated using the HSI Guidance [23], and then the level of disaster preparedness was determined. Each indicator in the HSI guidance was scored into one of the three different types of high (value: 1 ), average (value: 0.5 ), or low (value: 0 ). Every module was weighted based on the HSI guidance [28]. If a location has a higher risk of earthquake, the weighting for the scores of each module will be as follows: structural safety (50\%), nonstructural safety (30\%), and disaster and emergency management $(20 \%)$. The index part was calculated by multiplying the weight with the weighting ratio of each module [5,23].

Data collected were then evaluated using a univariate analysis. Significant information about variables and classification were then presented to describe the current situation of the emergency and disaster preparedness in the PHC. The scores from each module, namely the structural safety, nonstructural safety, and functional modules, were then averaged before being summed and divided by the number of modules. The index score interpretation based on the HSI guidance is represented in three different classifications as follows [23]:

- Category A (Hospital Safety Index of 0.66-1.00): Health facilities are considered able to remain fully operational when disasters strike. It is possible that the PHCs will remain functioning in the case of emergencies and disasters. However, it is suggested that the facility remains observant towards the best actions to improve emergency and disaster management capacity. Additionally, medium- and long-term actions need be carried out in order to improve the level of preparedness in health facilities to face emergencies and disasters.

- Category B (Hospital Safety Index of 0.36-0.65): Health facilities are able to recover from the disaster, but several services, including equipment and vital services, are exposed to danger. In this case, intervention measures are needed in the short term. Several aspects such as the current level of safety, emergency and disaster management, safety level of workers and patients, and the ability to remain functional during and after emergencies and disasters are possibly at risk.

- Category C (Hospital Safety Index of 0.00-0.35): Health facilities are considered unsafe for workers and patients during the disaster and need urgent interventions. The PHCs within this category are unlikely to function during and after emergencies and disasters. The levels of safety and emergency and disaster management within this range are inadequate to protect the lives of patients and workers during and after emergencies or disasters.

Descriptive statistics were performed through the measurement of the central tendency and were used for the value of structural, nonstructural, and functional aspect. The distribution of the value of structural, nonstructural, and functional aspect was tested by the normality.

Further analysis was then conducted using the multiple correspondence analysis (MCA) to describe the correlation mapping between the variables of the disaster preparedness level or HSI (dimension 1) and provinces under study (dimension 2). The MCA was 
applied to identify and characterize the basic pattern within the data [5,40]. The MCA permits a scientist to investigate the relationship configuration derived from some 206 categorically dependent variables and is used to study a set of observations, which are explained by a group of nominal variables [4,28]. In this research, the MCA was conducted using the SPSS software version 25.0 to create the map.

\section{Results}

The HSI is one of many disaster risk assessment tools, and it begins with the identification of disaster hazards faced by health facilities. Module 1 on HSI is an initial identification of potential hazards and disaster risks within the area around the PHCs that involves identifying potential hazards caused by geological phenomena (earthquakes, volcanic eruptions, landslides, and tsunamis), hydro-meteorological phenomena (hurricanes, torrential rains, storm surges or river flooding, and landslides), social phenomena (population density, displaced populations, strikes, protests, and proximity to high-security prisons), environmental health phenomena (epidemics, contamination, infestations, and other environmental phenomena), chemical and/or technological phenomena (explosions, fires, hazardous material spills/leaks, etc.), and considerations on geotechnical properties of soil. The results of hazard and disaster risks identification in Module 1 of the HSI $\mathrm{WHO} / \mathrm{PAHO}$ [23] revealed that hydro-meteorological and geological hazards were the most common relevant hazards. DKI Jakarta has various potential hazards and disasters, such as floods, strong winds, and landslides, with 22 disasters of various types occurring in 2020 [35]. Meanwhile, the West Java province is the province with the highest number of disasters among the 34 provinces in Indonesia with 623 natural disasters in 2020 alone [35]. Yogyakarta province experienced a 6.3 earthquake in 2006 [36], and the most powerful eruption of Mount Merapi in Yogyakarta occurred in 2010 [36,37]. A total of 15 mixed natural and non-natural disasters (COVID-19 pandemics) occurred in this province in 2020. In the meantime, North Sumatera province was also at a high risk of geological hazards, including earthquakes, landslides, and volcanic eruptions while also facing hydro-meteorological hazards such as floods, tsunamis (in some parts of North Sumatera), droughts, and forest fires [41]. This province recorded 92 disasters with various types during 2020 [35]. The four provinces shared common geological hazards of earthquakes, landslides, high winds, and volcanic eruptions while the most frequent hydro-meteorological hazards were floods and landslides due to saturated soil.

\subsection{Hospital Safety Index Score}

There were 11 (eleven) PHCs that participated in the study: 2 (two) PHCs in Jakarta (capital city of Indonesia), 3 (three) PHCs in West Java, three PHCs in Yogyakarta, and 3 (three) PHCs in North Sumatera. The 11 (eleven) PHCs had the HSI checklist fully completed. Module 1, which recognizes potential hazards that could lead to disasters and emergencies, is not incorporated in the calculation of the HSI. The results of the calculation of remaining modules are presented in Table 2.

Module 2 of HSI relates to the building construction and structural safety. The assessment was conducted based on the historical record of the PHCs, the structural design, and the types of building materials used. Table 3 shows detailed information results from Module 2 about the structural safety assessment, which are the core elements in determining the HSI score. The maximum score for Module 2 indicates the maximum score that can be achieved if the maximum value for each item is 1.00. The mean score in this study was determined from the average scores from the 11 PHCs, and the ratio was then derived by dividing the mean score with the maximum score. The calculation for each module was adopted from a previous study [5]. Table 3 demonstrates that, based on the assessment carried out, the total score of the PHCs in this study was 0.688 . This demonstrated that the overall score of structural safety modules 2 in this study was in the " $\mathrm{A}$ " category, meaning that the structural and construction safety of all PHC buildings was adequate for disaster preparedness. 
Table 2. HSI Score.

\begin{tabular}{|c|c|c|c|c|}
\hline No & Element & $\begin{array}{l}\text { Maximum } \\
\text { Score }\end{array}$ & Mean Score & Ratio \\
\hline \multicolumn{5}{|c|}{$\begin{array}{l}\text { Module 1: Potential hazards and disaster risks } \\
\text { It is an initial identification of potential hazards and disaster risks within the area around the } \\
\text { PHCs. It identifies potential hazards caused by geological phenomena (earthquakes, volcanic } \\
\text { eruptions, landslides, and tsunamis), hydro-meteorological phenomena (hurricanes, torrential } \\
\text { rains, storm surges or river flooding, and landslides), social phenomena (population density, } \\
\text { displaced populations, strikes, protests, and proximity to high-security prisons), environmental } \\
\text { health phenomena (epidemics, contamination, infestations, and other environmental phenomena), } \\
\text { chemical and/or technological phenomena (explosions, fires, hazardous material spills/leaks, } \\
\text { etc.), and also consideration of the geotechnical properties of soil. There is no score in this module. } \\
\text { Module 2: Structural Safety Aspects }\end{array}$} \\
\hline 1 & $\begin{array}{l}\text { Safety level related to } \\
\text { hospital histories }\end{array}$ & 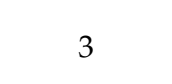 & 1.5 & 0.500 \\
\hline 2 & Building integrity & 11 & 8.136 & 0.740 \\
\hline Total scor & $\begin{array}{l}\text { odule } 2 \text { Structural Safety } \\
\text { aspects }\end{array}$ & 14 & 9.636 & 0.688 \\
\hline \multicolumn{5}{|c|}{ Module 3: Non-structural Safety Aspects } \\
\hline \multirow[t]{8}{*}{1} & Critical systems & & & \\
\hline & a. Electrical system & 5 & 3.409 & 0.682 \\
\hline & $\begin{array}{l}\text { b. Telecommunications } \\
\text { system }\end{array}$ & 4 & 2.682 & 0.670 \\
\hline & c. Water supply system & 6 & 4.364 & 0.727 \\
\hline & d. Fuel storage & 1 & 0.227 & 0.227 \\
\hline & e. Medical gas (oxygen) & 3 & 1.864 & 0.621 \\
\hline & f. Sanitation system & 3 & 2.364 & 0.788 \\
\hline & g. Drainage system & 1 & 0.455 & 0.455 \\
\hline 2 & HVAC & 2 & 1.409 & 0.705 \\
\hline 3 & $\begin{array}{l}\text { Office furniture and } \\
\text { fittings, storage } \\
\text { equipment }\end{array}$ & 4 & 2.273 & 0.568 \\
\hline 4 & $\begin{array}{l}\text { Laboratory and medical } \\
\text { equipment and supplies } \\
\text { used for diagnosis and } \\
\text { treatment }\end{array}$ & 2 & 1.455 & 0.727 \\
\hline 5 & Architectural component & 16 & 12.136 & 0.759 \\
\hline \multicolumn{2}{|c|}{$\begin{array}{l}\text { Total score for Module } 3 \text { Nonstructural Safety } \\
\text { Total Score }\end{array}$} & 47 & 32.636 & 0.694 \\
\hline \multicolumn{5}{|c|}{ Module 4: Functional Aspects } \\
\hline 1 & $\begin{array}{l}\text { Disaster committee } \\
\text { organization }\end{array}$ & 5 & 1.455 & 0.291 \\
\hline 2 & $\begin{array}{l}\text { Emergency or disaster } \\
\text { response plan }\end{array}$ & 21 & 9.045 & 0.431 \\
\hline 3 & $\begin{array}{l}\text { Readiness of medicines, } \\
\text { supplies, instruments, } \\
\text { and equipment for } \\
\text { disaster situation }\end{array}$ & 7 & 4.318 & 0.617 \\
\hline Total Score & ctional Aspects & 33 & 14.818 & 0.449 \\
\hline
\end{tabular}

Table 3. Overall hospital safety index.

\begin{tabular}{ccccc}
\hline No & Module & Weight & Ratio & Index \\
\hline 1 & Structural Safety & 50 & 0.688 & 0.344 \\
2 & Non-structural Safety & 30 & 0.694 & 0.208 \\
3 & Functional Aspects & 20 & 0.449 & 0.090 \\
& Overall Hospital Safety Index & & 0.642 \\
\hline
\end{tabular}


The non-structural safety module evaluates the critical systems, furniture, HVAC systems, laboratory equipment, storage units, medical equipment, office equipment, and architectural aspects of the PHCs. The results of the non-structural safety evaluation of the PHCs are also listed in Table 2. It was discovered that the ratio value of all PHCs in this study was 0.694 , or in the " $\mathrm{A}$ " category, which reflected good function of non-structural safety during emergencies and disaster in these PHCs. The functional elements of the PHCs were evaluated based on the readiness of the PHC disaster committee and disaster response plan, as well as the readiness of medicines, instruments, supplies, and equipment for disaster conditions. Table 2 also lists the results of the functional element evaluation in the PHCs with an overall score for the functional aspect of 0.449 in the four provinces. This classified the PHCs in the " $\mathrm{B}$ " classification, meaning that there were still risks in the functional aspect when dealing with disasters.

\subsection{Overall Hospital Safety Index}

Table 3 demonstrates that the overall safety index for all samples in all provinces was 0.642 . It was interpreted that the hospitals in this study were classified into category B (HSI 0.36-0.65), which means that intervention actions are needed in the short-term. From the perspective of the PHC's level of safety, emergency and disaster management that includes the safety of workers and patients and the ability of each PHCs to fully function during and after emergencies and disasters, these aspects were possibly at risk during and after emergencies and during disasters. The calculation of each hospital's safety index is based on the weighting of the respective modules. The values for structural components represent $50 \%$ of the total values in the index, nonstructural components represent $30 \%$, and the functional capacity represents $20 \%$. This model is proposed for countries or regions where there is a higher risk of structural and nonstructural failure, as in high earthquake-prone or high-wind areas such as in North Sumatera, Jakarta, West Java, and Yogyakarta. The index part was calculated by multiplying the weight with the weighting ratio of each module.

\subsection{Comparison of HIS Scores in All Provinces}

To gain an overview of all research locations, a comparison was made of the average score and ratio of each research area. The results of the description and comparison of each province are presented in Table 4.

Table 4. Comparison of HSI score in all provinces.

\begin{tabular}{|c|c|c|c|c|c|c|c|c|c|}
\hline \multirow{2}{*}{ No } & \multirow{2}{*}{ Item } & \multicolumn{2}{|c|}{ DKI Jakarta } & \multicolumn{2}{|c|}{ West Java } & \multicolumn{2}{|c|}{ North Sumatera } & \multicolumn{2}{|c|}{ Yogyakarta } \\
\hline & & Ratio & Level & Ratio & Level & Ratio & Level & Ratio & Level \\
\hline \multicolumn{10}{|c|}{ Module 1: Potential hazards and disaster risks } \\
\hline & $\begin{array}{l}\text { Describe potential hazards } \\
\text { and disaster risks faced } \\
\text { surrounding PHCs }\end{array}$ & $\begin{array}{r}\text { DKI Ja } \\
\text { poten } \\
\text { disaste } \\
\text { strong wir }\end{array}$ & $\begin{array}{l}\text { various } \\
\text { ls and } \\
\text { floods, } \\
\text { quake and } \\
\text {. }\end{array}$ & $\begin{array}{l}\text { West Java } \\
\text { and dis } \\
\text { earthqu } \\
\text { volcani }\end{array}$ & $\begin{array}{l}1 \text { hazards } \\
\text { such as } \\
\text { dslides, } \\
\text { ns, and }\end{array}$ & $\begin{array}{r}\text { North Sun } \\
\text { haza } \\
\text { earthqua } \\
\text { volcanic } \\
\text { tsunami } \\
\text { North Su } \\
\text { an }\end{array}$ & $\begin{array}{l}\text { s potential } \\
\text { ding } \\
\text { ides, and } \\
\text { s, floods, } \\
\text { parts of } \\
\text { droughts, } \\
\text { res. }\end{array}$ & $\begin{array}{l}\text { Yogye } \\
\text { hig } \\
\text { earthe } \\
\text { volcan }\end{array}$ & $\begin{array}{l}a \text { is at } \\
\text { to } \\
\text { es and } \\
\text { aptions }\end{array}$ \\
\hline \multicolumn{10}{|c|}{ Module 2: Structural safety aspects } \\
\hline 1 & $\begin{array}{l}\text { Safety Level related to } \\
\text { hospital's histories }\end{array}$ & 0.500 & B & 0.556 & B & 0.611 & B & 0.333 & $\mathrm{C}$ \\
\hline 2 & Building Integrity & 0.773 & A & 0.591 & B & 0.848 & A & 0.758 & A \\
\hline & Module 2 Total & 0.769 & A & 0.583 & B & 0.798 & A & 0.667 & A \\
\hline \multicolumn{10}{|c|}{$\begin{array}{c}\text { Module 3: Non-structural safety aspects } \\
\text { Critical system }\end{array}$} \\
\hline \multirow{7}{*}{3} & a. Electrical system & 0.650 & B & 0.700 & $\mathrm{~A}$ & 0.667 & A & 0.700 & $\mathrm{~A}$ \\
\hline & $\begin{array}{l}\text { b. Telecommunications } \\
\text { system }\end{array}$ & 0.813 & A & 0.625 & B & 1.000 & A & 0.500 & B \\
\hline & c. Water supply system & 0.333 & $\mathrm{C}$ & 0.889 & A & 0.722 & A & 0.639 & B \\
\hline & d. Fuel storage & 0.250 & $\mathrm{C}$ & 0.333 & $\mathrm{C}$ & 0.000 & $\mathrm{C}$ & 0.333 & $\mathrm{C}$ \\
\hline & e. Medical Gas (Oxygen) & 0.621 & B & 0.722 & A & 0.944 & A & 0.500 & B \\
\hline & f. Sanitation System & 0833 & $\mathrm{~A}$ & 0.944 & A & 0.722 & A & 0.667 & $\mathrm{~A}$ \\
\hline & g. Drainage System & 0.750 & A & 0.667 & $\mathrm{~A}$ & 0.000 & $\mathrm{C}$ & 0.500 & B \\
\hline
\end{tabular}


Table 4. Cont.

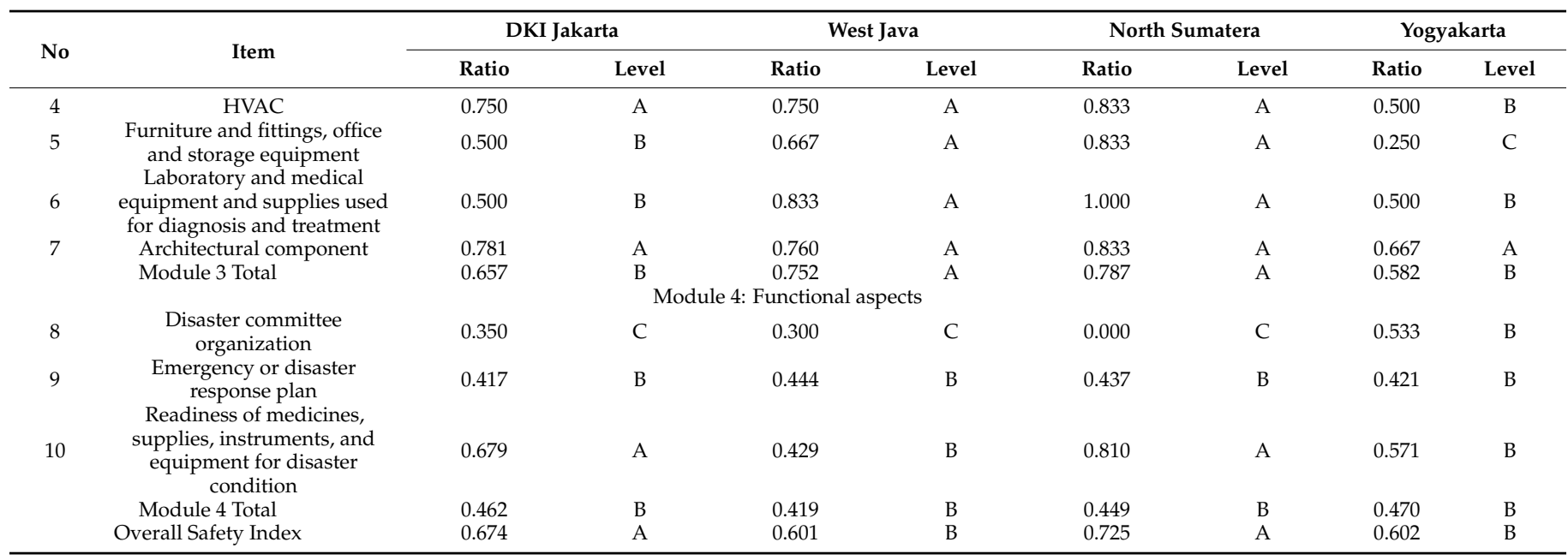

From the analysis, the HSI in Jakarta and North Sumatera was observed between 0.66 and 1.00, or category " $\mathrm{A}$ "; thus, the PHCs in these provinces were likely to remain operational in the case of a disaster. In contrast, the PHCs in West Java and Yogyakarta provinces had the HSI of between 0.36 and 0.65 , or category " $\mathrm{B}$ ".

\subsection{Multiple Correspondence Analysis}

Multiple correspondence analysis (MCA) was utilized for further analysis to determine the relationship between categorical variables. The analysis summary of MCA analysis is shown in Table 5 (Model Summary) and Figure 2 (Joint Plot Category). The model summary showed that the two-dimensional space captured a representative $100 \%$ of the total variance in the data group, and every dimension resulted an eigenvalue that was higher than 1. Dimension 1 indicates the level of HSI in PHCs, whereas dimension 2 indicates the number of case study provinces.

Table 5. Multiple correspondence analysis model summary (derived from SPSS).

\begin{tabular}{ccccc}
\hline Dimension & Cronbach's Alpha & Total Eigenvalue & Inertia & \% of Variance \\
\hline $\begin{array}{c}\text { 1 (level of HSI in } \\
\text { PHCs) }\end{array}$ & 0.829 & 2.646 & 0.662 & 66.151 \\
2 (case study & 0.359 & 1.368 & 0.342 & 34.200 \\
provinces) & & 4.014 & 1.004 & $100 \%$ \\
$\quad$ Total & 0.669 & 2.007 & 0.502 & 50.176 \\
Mean & & &
\end{tabular}

Multiple correspondence analysis (MCA) was utilized for further analysis to determine the relationship between categorical variables. The analysis summary of MCA analysis is shown in Table 4 (Model Summary) and Figure 2 (Joint Plot Category). Eigenvalues depict the relative relevance of each dimension to the total inertia (it is normalized to 1 , which stands for all the information of all the variables in the dimensions). The highest eigenvalue was always in the first dimension, progressively decreasing across the following dimensions. Inertia illustrates the dispersion of data and is considered as a measure of information of data. This variable (together with the total inertia) is commonly used to select the maximum number of dimensions to be included in the MCA map and analysis. Thus, dimensions with an eigenvalue lower than 0.05 are usually not considered. Based on the table above, eigenvalues are more than 1 , which means that the dimensions are considered. The total variance percentage for each dimension is explained by the inertia (eigenvalue). Dimension 1 has an inertia value of 0.662 , meaning that the variance of the indicator matrix for the first dimension is $0.662(66.2 \%)$. While the value of inertia 
dimension 2 is $0.342(34.2 \%)$. The value of the proportion of inertia shows the proportion of the main inertia of the indicator matrix to the total inertia.

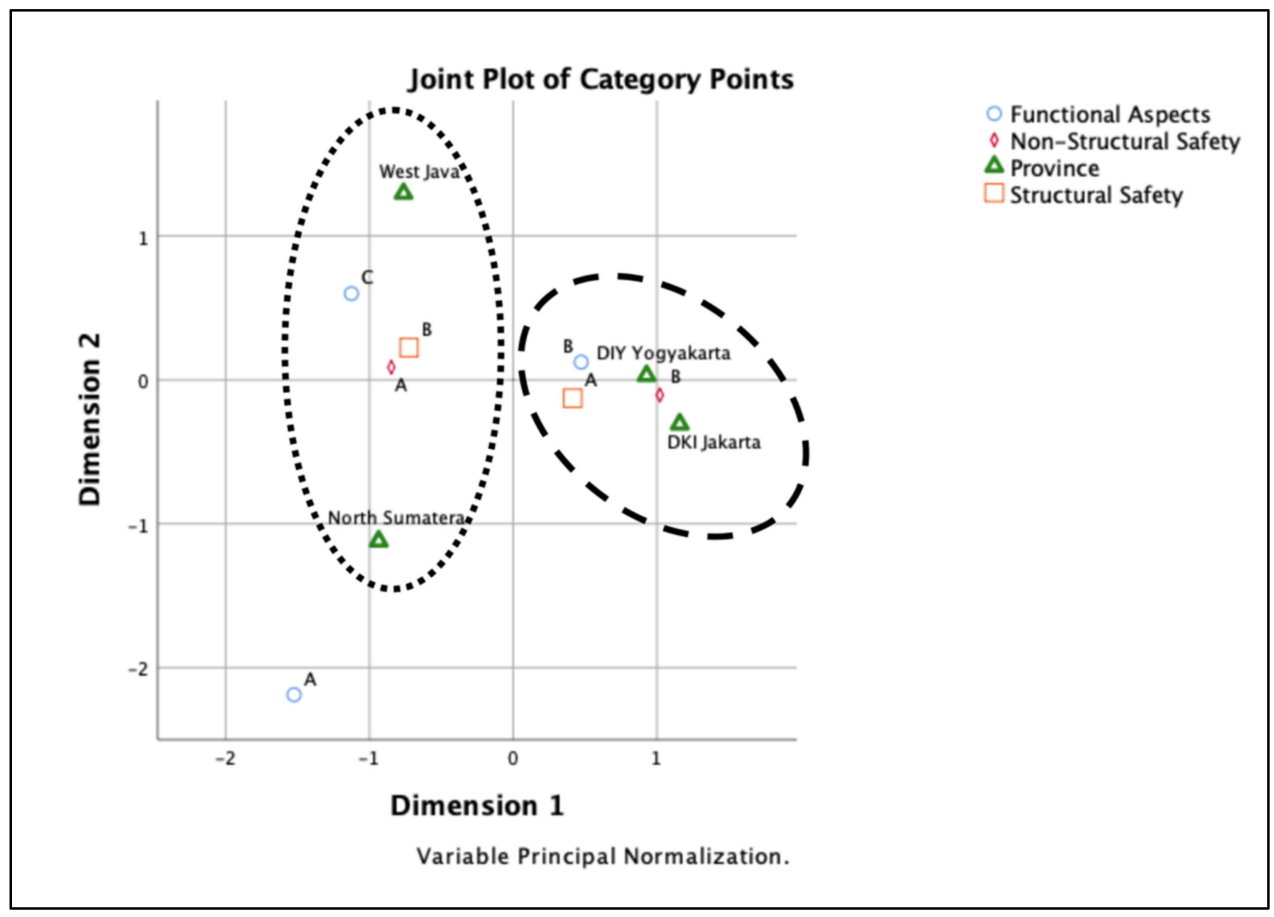

Figure 2. Multiple correspondence analysis.

The model summary showed that the two-dimensional space captured a representative $100 \%$ of the total variance in the data group, and every dimension resulted an eigenvalue that was higher than 1. Dimension 1 indicates the level of HSI in PHCs, whereas dimension 2 indicates the number of case study provinces. The joint category plot as presented in Figure 2 shows that the two groups of clouds, (-) and (...), produced by classification are closely related. The classification cloud on the joint plot above was clustered based on the distance between points. The first classification cloud (-) shows that the PHCs in the provinces of Yogyakarta and DKI Jakarta tended to have similar aspects in Modules 2 (structural safety) and 3 (nonstructural safety). The similarity between Jakarta and Yogyakarta provinces were classified as structural safety in category "A," nonstructural safety in category "B," and functional aspects in category "B."

The second classification cloud (... ) shows that the PHCs in the province of North Sumatera and West Java tended to have category " $\mathrm{A}$ " for nonstructural safety aspects, category " $\mathrm{B}$ " for structural safety, and category " $\mathrm{C}$ " for functional aspects. From the MCA analysis above, the functional aspects for the overall PHCs studied tended to be far from category " $\mathrm{A}$ " and closer to category "B." PHCs in West Java province were closer to the " $\mathrm{C}$ " category for functional aspect. Research conducted on the HSI assessment of hospitals in Yogyakarta and West Java province in 2019 found that class C hospitals in Indonesia have a relatively low HSI index and require critical improvements [5].

\section{Discussion}

\subsection{Potential Hazards and Disaster Risks}

The areas of study, which include four provinces of DKI Jakarta, West Java, North Sumatera, and Yogyakarta, have similar potential disaster hazards, especially geologically and hydro-meteorologically. The most frequent disasters in Indonesia were floods (1080 events), followed by strong winds (880 events), landslides (577 events), forest and land fires (326 events), tidal waves and abrasions (36 events), droughts (29 events), earthquakes (16 events), volcanic eruptions (7 events), and pandemics (1 event) [35]. 
Based on the long history of disasters in Indonesia, Yogyakarta and West Java Province have extensive experience in facing earthquakes that cause damage to buildings, including healthcare facilities [42,43]. Yogyakarta and West Java Provinces also have vast experience with volcanic eruptions and deadly landslides $[38,44]$. In addition, North Sumatera Province is at risk for volcanic eruptions, floods, and landslides, while the DKI Jakarta Province has various potential disasters, with the most frequent disaster being floods. With its position as the capital city of Indonesia, as well as being a metropolitan city, DKI Jakarta province has a high population density that can lead to social problems. In terms of potential hazards and disasters in these four provinces, earthquakes, volcanic eruptions, and floods are the main threats to the study area. The hazard mapping of the area around healthcare facilities, especially for disaster-prone areas, is important, as stated by research conducted in several hospitals. The research revealed that hospitals in earthquake-resistant buildings can deliver better medical services to their beneficiaries [45]. In the four provinces under study, the common geological hazards are earthquakes, landslides, strong winds, and volcanic eruption, whereas the most frequent hydro-meteorological hazards are floods and landslides due to saturated soil.

\subsection{Structural Safety}

Indonesia is a disaster-vulnerable nation; it is located in a dangerous area where almost $90 \%$ of the globe's earthquakes happen in this region. Indeed, Indonesia is the location of $15 \%$ of the earth's active volcanoes, making the existence of earthquakes, volcanic eruptions, and tsunamis more frequent $[46,47]$. Hence, this high-risk situation means that the structural safety element in HSI has become the most important element for hospital readiness in facing emergencies and disasters. Many healthcare facilities including primary healthcare have been damaged during Lombok's and Palu's earthquakes due to incompliance with structural safety $[48,49]$.

Structural safety assessment involves assessing the level of safety related to hospitals' histories and building integrity. The results of the assessment carried out at the 11 PHCs indicate that there are four PHCs in category B (two in West Java province; one in North Sumatera province; one in Yogyakarta province) and seven PHCs in category A. Overall, in the assessment by referring to the PAHO guideline, there were three aspects of concern in almost all PHCs under study regarding whether PHC was built and/or refurbished according to the existing safety standard; effect of modification or remodeling on the construction behavior of the PHCs; and structural detailing, including connections. These structural safety issues occurred because the PHCs in this study occupied relatively old buildings dated from the 1990s. In addition, in Yogyakarta Province, which experienced a major disaster in 2006, it was found that the PHCs had experienced severe structural damage. Research conducted in two European countries, Serbia and Croatia, revealed that the problem often faced by health services is infrastructure-related problems, specifically the structural safety aspect. From this research, it is known that many healthcare facility buildings are old [50]. Evaluation results for structural safety is useful for prioritizing structural renovation and reconstruction. Indeed, the building structural requirement should be in compliance with the ministry of Health No. 43 Year 2019 about Primary Healthcare [1], Indonesia Law Act no No.28 Year 2002, and Government Regulation No 16 Year 2021 about Buildings [51,52] which stated the requirements for PHCs to be built as earthquake-resistant buildings. The results from this study can provide the best solutions for local government and Indonesia's ministry of health for future improvement, particularly for PHC buildings. The objectives for this compliance to building structural requirement are ensuring that PHCs can continuously deliver healthcare services during and post-disasters.

Previous research has shown that the PAHO index can be used to compare the structural/seismic safety of different hospitals. It is effective for prioritizing treatments rather than an absolute appraisal, which necessitates a thorough examination [25]. The Hospital Safety Index (HSI) is commonly used to assess hospital resiliency for various types of emergencies and disasters [23]. Hospital resiliency during emergencies and disasters can 
also be measured using the Hospital Emergency and Disaster Management Index using the TOPSIS method [10].

\subsection{Non-Structural Safety}

Non-structural safety is a key factor for healthcare to continue to remain operational in case of an electrical blackout. Java Island, at which DKI Jakarta, West Java, and Yogyakarta are located, experienced a massive blackout in 2019 [53]. The blackout ceased after an unusually long period of electrical blackout for 2 days in a certain area, while remaining for 3 days in other areas. This situation has taught the healthcare facilities to be more prepared in case a similar electrical blackout occurs. Healthcare facilities need to be ready for up to 3 days without electricity by preparing several methods to remain operational, including fuel storage and electricity back-ups.

In non-structural safety, five aspects were assessed, including critical (lifeline) systems; systems for heating; air conditioning; ventilation; and/or hot water, furniture, storage units and office equipment, medical and laboratory equipment, and supplies used for diagnosis and treatment, and architectural elements. The results of the assessment show that the PHCs in the provinces of DKI Jakarta and Yogyakarta are in category " $\mathrm{B}$ " for this nonstructural element, and the PHCs in the provinces of West Java and North Sumatera are in category "A." Based on the overall assessment, it is observed that there are four main issues in all PHCs in all provinces: fuel storage, medical gases, safety of cupboard and shelf contents, and protection of furniture and fittings. A cross-sectional survey conducted on health services in Malaysia regarding the nonstructural assessment of preparedness indicates that the nonstructural safety aspect is in the very-critical category and needs immediate improvements, especially laboratory and medical equipment and supplies for diagnostic and treatment [54]. Regarding laboratory and medical equipment, similar research in Japan also suggests that in nonstructural aspects, medicine management implementation is crucial in healthcare services [45]. There are also interesting findings in PHCs in DKI Provinces regarding the fire protection system. PHCs in DKI Provinces have good fire protection systems compared with other provinces because the local government has strict regulations about fire protection. This might be due to the fact that DKI Jakarta Province is the capital and biggest city in Indonesia, making the fire risks greater than in smaller cities. It is important to manage fire hazards in areas with high population density, especially through building fire safety regulatory system capacity on the city level [55]. The lack of regulatory system has been shown to result in tragic incidents, such as the catastrophic fire incident that occurred in a COVID-19 ward in al-Hussain hospital in Southern Iraq, which claimed 92 lives and injured 100 people. The investigation report of this incident indicated that the hospital was not ready for a fire incident, which was reflected from the lack of fire alarms and sprinklers, limited hospital response plan, and unready emergency response team $[20,21]$. This catastrophic incident indicated the importance of HSI assessment and any gaps identified to be corrected in order to ensure the safety of patients and workers.

\subsection{Functional Aspect}

The most recurring areas of extreme-event and disaster occurrence are located in Java and Sumatra Island [3]. There are 5 (five) provinces in Indonesia that have been considered as highly disaster-prone areas based on extreme-event and disaster frequencies, which has consequences on human health: Central Java, DKI Jakarta, West Java, East Java, and North Sumatra [3]. The readiness of healthcare in facing various types of extreme events and disasters is deemed to be important, particularly the readiness of disaster committee and its capacity to conduct evacuation $[11,12]$.

The result of the functional aspect assessment demonstrated that this aspect obtains the lowest score compared to the other two aspects. It is revealed that, of the 11 PHCs of the study area, only one PHC was in the " $\mathrm{A}$ " category, whereas the other 10 PHCs were in either category " $\mathrm{B}$ " or " $\mathrm{C}$ ". The PHC in category " $\mathrm{C}$ " is located in West Java Province. One of the assessment items for this functional aspect is the availability of the 
PHC's emergency/disaster committee. From the overall assessment carried out, the PHCs located in Yogyakarta Province already have a formally established emergency/disaster committee, which is run by the PHC's management staff. The importance of PHC disaster committee organizations has been indicated from other research [56], at which PHC disaster committees could implement the disaster management in case of emergencies or disasters [56].

The experience of a major disaster that occurred several years ago in Yogyakarta Province has increased the awareness for improvement. What needs to be considered from this aspect assessment is that many PHCs do not yet have an emergency response plan or emergency response training for personnel. The emergency response plan is one of the key factors in disaster risk reduction, particularly minimizing the impact of disasters to patients, visitors, and workers [10-12]. Without a good emergency response plan, PHCs patients, visitors, and workers are at high risk during emergencies and disaster situations [10-12].

Personnel training is often an issue in implementing emergency and disaster management. This is in line with other research on PHCs in Iran, where the HSI index for the training and training personnel aspect is considerably low [57]. The results of the MCA also show that from all aspects of the assessment using the HSI instrument, the PHCs in all assessment provinces tended to be closer to category " $\mathrm{B}$ " and required improvement. PHCs need to prioritize an effort to fulfill these functional aspects to reduce the risks to PHC patients, workers, and visitors.

\subsection{Overall Hospital Safety Index}

The overall score of the HSI for the PHCs in Jakarta (0.674) and North Sumatera $(0.752)$ were between 0.66 and 1.00 or in category " $\mathrm{A}$ ", meaning that they will likely remain operational in the case of disaster. The PHCs in West Java (0.601) and Yogyakarta (0.602) provinces achieved a score of between 0.36 and 0.65 , i.e., in category " $\mathrm{B}$ ". There are many things that can be learned from this HSI assessment for PHCs, and the PHCs can perform gap analysis about which aspects they need to improve. Several aspects need to be improved for PHCs in Jakarta, including water-supply systems, fuel storage, and disaster committee organization (category " $\mathrm{C}^{\prime \prime}$ ), whereas for North Sumatera, improvements must be made in fuel storage and disaster committee organization (category " $\mathrm{C}^{\prime \prime}$ ). Some aspects need to be improved in PHCs in West Java including fuel storage and disaster committee organization, while in Yogyakarta, buildings that have weathered disasters in the past are in need of attention to reduce the risk of damages from future disasters. Other areas of improvement include fuel storage, furniture and fittings, and office and storage equipment (category " $\mathrm{C}^{\prime}$ ). As Yogyakarta has experienced many disasters, it appears that PHCs in Yogyakarta are more prepared by forming the disaster committee organizations. In general, no location stores enough fuel to maintain operations for $72 \mathrm{~h}$ per WHO/PAHO recommendations. Normally, PHCs only have fuel storage up to $24 \mathrm{~h}$, which is not enough in the case of a disaster because power and fuel may not be restored immediately after the incident. Other research has indicated the importance of fuel storage, especially during flood situations [56], and PHCs in Jakarta and West Java provinces are prone to floods. As we learned from the West Java blackout in 2019 [58], as well as Jakarta's floods over the past 10 years [59], PHCs in Jakarta need to improve their fuel storage capacity as soon as possible.

As for disaster committee organizations, only Yogyakarta has formed one, whereas the other three locations have not, and this needs urgent rectification as Indonesia is prone to various types of disasters. Lessons learned from other research indicates the importance of PHC disaster committee organizations, which can direct and lead the disaster management in case of emergencies or disasters [56]. 


\section{Conclusions}

\subsection{Conclusions}

It is critical that PHCs remain operational after major emergencies and disasters. The role of PHCs has been critical during the pandemic, as there are increasing activities in PHCs as the front line to conduct pandemic prevention and control transmission. It is crucial that PHCs' capability to remain operational during disaster is maintained, especially when facing the combination of the current pandemic and other disaster hazards. Our research indicates that the HSI score for PHCs in Jakarta (0.674) and North Sumatera (0.752) is between 0.66 and 1.00 or category " $\mathrm{A}$ ", meaning that they are likely to remain operational in the case of disaster. However, PHCs in Jakarta and North Sumatera need to improve their water supply system, fuel storage, and disaster committee organization, which fall into category "C". PHCs in West Java (0.601) and Yogyakarta (0.602) fall between 0.36 and 0.65 , i.e., category " $\mathrm{B}$ ". In particular, PHCs in West Java need to improve their fuel storage and establish a disaster committee organization. Given Yogyakarta's 10 years of disasters that have affected the structural safety of PHC buildings, the city needs to prioritize the inspection and repair of buildings to protect patients, staff, and the greater community. PHCs in Yogyakarta should also be concerned with other aspects of disaster preparedness, including fuel storage, furniture and fittings, and office and storage equipment, which fall into category " $\mathrm{C}$ ". Since Indonesia is a country that is prone to disasters, it is highly recommended that all PHCs in Indonesia form disaster committee organizations to be better prepared for disasters. Currently, only PHCs in Yogyakarta have formed a disaster committee, whereas the other three locations have not yet done so. The HSI using $\mathrm{WHO} / \mathrm{PAHO}$ for small and medium health facilities can be used to assess the disaster preparedness of the PHCs.

\subsection{Recommendation}

This present study is a preliminary screening which is able to provide an insight into major urgencies such as primary healthcare. Therefore, further analysis and investigation needs to be conducted in other areas. In addition, there are several recommendations for the Indonesian government to better promote PHC disaster preparedness. Firstly, intervention measures need to be improved, particularly for items that fall into category " $\mathrm{C}$ ", such as building structural safety, water supply system, fuel storage, disaster committee organization, furniture and fittings, and offices and storage equipment. Secondly, broader assessments of PHCs for their readiness in facing major disasters and emergencies, particularly in high disaster risk areas, need to be made. A broader assessment of PHCs on their readiness for emergency and disasters will be useful for identifying the most susceptible PHCs in the vulnerable locations. Thirdly, re-assessments need to be made of the disaster readiness of PHCs in the high-disaster-risk areas after intervention measures are implemented and, lastly, increased capacity of PHCs for disaster risk reduction efforts, including capacity building for PHCs workers, should be facilitated. This can be achieved through a structured and systematic training framework for PHC workers to ensure that the knowledge and information gained is maintained in the PHCs where improvements have been made, so that they will be able to continuously monitor and uphold their level of disaster readiness capability. Results from HSI assessment in PHCs can be used to prioritize resource allocation, effective cost planning, providing specific solutions for government, and efforts towards disaster risk reduction.

\subsection{Limitations of Study}

This study has several limitations. First, the sample size is small, with only 11 PHCs from 4 provinces studied. Participation of more PHCs from various provinces in Indonesia is needed to assess the PHCs' disaster readiness, particularly in disaster-prone areas, in Indonesia. Second, due to the pandemic, most data collection was conducted virtually and online using an online questionnaire and virtual FGDs. Some physical assessments were conducted using only photos and videos. Further data analysis using multivariate 
approach should be considered to determine which variable is the most significant factor in disaster preparedness. The use of WHO/PAHO HSI for small and medium health facilities for assessing PHCs' disaster readiness can be observed in broader locations and variations.

Author Contributions: Conceptualization, F.L., D.P., and A.K.; methodology, F.L., D.P., A.K., N.A.F., and A.Y.H.; software, F. and A.I.; validation, A.Y.H., S., H.J.E.-M., and O.W.; formal analysis, A.I., A.K., D.P., and F.L.; investigation, N.A.F., A.K., and D.P.; writing-original draft preparation, F.L., D.P., A.K., N.A.F., A.Y.H., S., H.J.E.-M., O.W., and A.I.; writing-review and editing, F.L., D.P., A.K., N.A.F., F., A.Y.H., S., H.J.E.-M., O.W., and A.I.; visualization, A.K., D.P., and A.I.; supervision, F.L.; project administration, N.A.F. All authors have read and agreed to the published version of the manuscript.

Funding: The authors would like to thank Universitas Indonesia for funding this research through PUTI Grant with the contract number of NKB-1621/UN2.RST/HKP.05.00/2020.

Institutional Review Board Statement: The study was conducted according to the guidelines of the Declaration of Helsinki. The research was conducted based on the research ethics guideline and have been approved under approval letter No. 436/UN2.F10.D11/PPM.00.02/2020 from the Ethics Committee of the Faculty of Public Health, Universitas Indonesia. Informed consent was obtained from the subject participant involved in the study.

Data Availability Statement: The dataset utilized and/or analyzed during the present study are available on reasonable request from the corresponding author.

Acknowledgments: The authors would like to thank local health authorities in the provinces of DKI Jakarta, West Java, Yogyakarta, and North Sumatera for providing access to all relevant data and information. In addition, the authors would like to acknowledge all key informants who were willing to participate during the interview and focus group discussion.

Conflicts of Interest: The authors declare no conflict of interest.

\section{References}

1. The Ministry of Health Republic Indonesia. Peraturan Menteri Kesehatan Republic Indonesia Nomor 43 Tahun 2019; The Ministry of Health Republic Indonesia: Jakarta, Indonesia, 2019. [CrossRef]

2. Cooperazione Internazionale. Safe Hospitals: Key Practices for DRR Implementers, First; Cooperazione Internazionale: Milano, Italy, 2014.

3. Haryanto, B.; Lestari, F.; Nurlambang, T. Extreme Events, Disasters, and Health Impacts in Indonesia. In Extreme Weather Events and Human Health; Springer Nature Switzerland AG: Cham, Switzerland, 2020. Available online: https:/ /www.springerprofessional. de/en/extreme-events-disasters-and-health-impacts-in-indonesia/17394024 (accessed on 26 September 2021).

4. The Ministry of Health Republic Indonesia. Technical Guidance of Public Health Center Services during COVID-19 Pandemic; The Ministry of Health Republic Indonesia: Jakarta, Indonesia, 2020.

5. Sunindijo, R.Y.; Lestari, F.; Wijaya, O. Hospital safety index: Assessing the readiness and resiliency of hospitals in Indonesia. Facilities 2019, 38, 39-51. [CrossRef]

6. Samsuddin, N.M.; Takim, R.; Nawawi, A.H.; Syed Alwee, S.N.A. Disaster Preparedness Attributes and Hospital's Resilience in Malaysia. Procedia Eng. 2018, 212, 371-378. [CrossRef]

7. UNISDR. Hyogo Framework for Action 2005-2015: Building the Resilience of Nations and Communities to Disasters; United Nations Office for Disaster Risk Reduction: Geneva, Switzerland, 2005; pp. 508-516. [CrossRef]

8. UNISDR. Sendai Framework for Disaster Risk Reduction 2015-2030; United Nations Office for Disaster Risk Reduction: Geneva, Switzerland, 2015; 32p. Available online: https://www.undrr.org/publication/sendai-framework-disaster-risk-reduction-2015-2 030 (accessed on 2 November 2021).

9. Rasanathan, K.; Evans, T.G. Primary health care, the Declaration of Astana and COVID-19. Bull. World Health Organ. 2020, 98, 801-808. [CrossRef]

10. Mojtahedi, M.; Sunindijo, R.Y.; Lestari, F.; Suparni, S.; Wijaya, O. Developing hospital emergency and disaster management index using topsis method. Sustainability 2021, 13, 5213. [CrossRef]

11. Yazdani, M.; Mojtahedi, M.; Loosemore, M.; Sanderson, D.; Dixit, V. Hospital evacuation modelling: A critical literature review on current knowledge and research gaps. Int. J. Disaster Risk Reduct. 2021, 66, 102627. [CrossRef]

12. Aghapour, A.H.; Yazdani, M.; Jolai, F.; Mojtahedi, M. Capacity planning and reconfiguration for disaster-resilient health infrastructure. J. Build. Eng. 2019, 26, 100853. [CrossRef]

13. BNPB. IRBI Indeks Risiko Bencana Indonesia Tahun. 2020. Available online: https://inarisk.bnpb.go.id/pdf/BUKU\%20IRBI\%20 2020\%20KP.pdf (accessed on 15 September 2021).

14. National Disaster Management Agency. Disasters in Indonesia 2020; National Disaster Management Agency: Jakarta, Indonesia, 2020 . 
15. Lestari, F.; Hasbullah, T.; Haryanto, B.; Ronoatmodjo, S.; Purwana, R.; Trihandini, I.; Utomo, B.; Pratomo, H.; Wiweko, B.; Kasali, R.; et al. Indonesia's Experience in COVID-19 Control Period Junuary-July 2020; Badan Nasional Penanggulangan Bencana: Jakarta, India, 2020; ISBN 9786027700192.

16. Dinas Kesehatan Provinsi Nusa Tenggara Barat. Data Sementara Kerusakan Fasilitas Kesehatan Akibat gempa Bumi Lombok; Dinas Kesehatan Provinsi Nusa Tenggara Barat: Mataram, Indonesia, 2020. Available online: https://dinkes.ntbprov.go.id/berita/datasementara-kerusakan-fasilitas-kesehatan-akibat-gempa-bumi-lombok/ (accessed on 17 November 2021).

17. Pemerintah Provinsi Sulawesi Tengah. Laporan Finalisasi Data dan Informasi Bencana Gempa Bumi, Tsunami dan Likuifaksi di Sulawesi Tengah per Tanggal 20 des 2018; Pemerintah Provinsi Sulawesi Tengah: Palu, Indonesia, 2018; 14p. Available online: https:/ /www. humanitarianresponse.info/sites/www.humanitarianresponse.info/files/documents/files/lap_ke_gub_20_des_2018.pdf (accessed on 16 September 2021).

18. Satgas COVID-19. Peta Seberan COVID-19. Available online: https:/ covid19.go.id/peta-sebaran (accessed on 12 November 2021).

19. The Ministry of Health Republic Indonesia. New Normal in the Health Services in Primary Health Care during COVID-19 Pandemic; The Ministry of Health Republic Indonesia: Jakarta, Indonesia, 2021.

20. Rasheed, A.; Al-Saih, M. Anger mounts after 92 die in fire on Iraq COVID ward. Reuters, 2021. Available online: https://www. reuters.com/world/middle-east/deaths-iraqs-coronavirus-hospital-fire-rise-64-ina-2021-07-13/ (accessed on 10 September 2021).

21. BBC. Iraq hospital fire: Protests as Covid ward blaze kills at least 92. BBC, 2021. Available online: https://www.bbc.com/news/ world-middle-east-57814954 (accessed on 11 September 2021).

22. Pan American Health Organization. Hospital Safety Index: Evaluation of Small and Medium-Sized health Facilities; PAHO: Washington, DC, USA, 2011; Volume 3.

23. PAHO/WHO. Hospital Safety Index: Medium and Small Hospitals Safety Index, 4th ed.; Pan American Health Organization: Washington, DC, USA, 2015.

24. Santarsiero, G.; Di Sarno, L.; Giovinazzi, S.; Masi, A.; Cosenza, E.; Biondi, S. Performance of the healthcare facilities during the 2016-2017 Central Italy seismic sequence. Bull. Earthq. Eng. 2019, 17, 5701-5727. [CrossRef]

25. Masi, A.; Santarsiero, G.; Gallipoli, M.R.; Mucciarelli, M.; Manfredi, V.; Dusi, A.; Stabile, T.A. Performance of the health facilities during the 2012 Emilia (Italy) earthquake and analysis of the Mirandola hospital case study. Bull. Earthq. Eng. 2014, 12, $2419-2443$. [CrossRef]

26. Aiello, M.A.; Pecce, M.; Sarno, L.D.; Perrone, D.; Rossi, F. A Safety Index for Hospital Buildings. Disaster Adv. $2012,5,270-277$.

27. WHO; PAHO. Hospital Safety Index: Guide for Evaluators 2nd Edition; Pan American Health Organization: Washington, DC, USA, 2015; 174p.

28. Adini, B.; Goldberg, A.; Laor, D.; Cohen, R.; Zadok, R.; Bar-Dayan, Y. Assessing levels of hospital emergency preparedness. Prehosp. Disaster Med. 2006, 21, 451-457. [CrossRef]

29. Lazar, E.J.; Sr, N.V.C.; Gebbie, K.M. Are We Ready and How Do We Know? The Urgent Need for Performance Metrics in Hospital Emergency Management. Disaster Med. Public Health Prep. 2008, 3, 57-60. [CrossRef] [PubMed]

30. Top, M.; Gider, Ö.; Tas, Y. An Investigation of Hospital Disaster Preparedness in Turkey. J. Homel. Secur. Emerg. Manag. 2011, 7. [CrossRef]

31. Higgins, W.; Wainright, C.; Lu, N.; Carrico, R. Assessing hospital preparedness using an instrument based on the Mass Casualty Disaster Plan Checklist: Results of a statewide survey. Am. J. Infect. Control 2004, 32, 327-332. [CrossRef] [PubMed]

32. Kaji, A.H.; Lewis, R.J. Hospital Disaster Preparedness in Los Angeles County. Acad. Emerg. Med. 2006, 13, 1198-1203. [CrossRef]

33. Kaji, A.H.; Langford, V.; Lewis, R.J. Assessing Hospital Disaster Preparedness: A Comparison of an On-Site Survey, Directly Observed Drill Performance, and Video Analysis of Teamwork. Ann. Emerg. Med. 2008, 52, 195-201. [CrossRef]

34. Kollek, D.; Cwinn, A.A. Hospital emergency readiness overview study. Prehosp. Disaster Med. 2011, 26, 159-165. [CrossRef]

35. National Disaster Management Agency. Geoportal Disaster in Indonesia; National Disaster Management Agency: Delhi, India.

36. MacRae, G.; Hodgkin, D. Half full or half empty? Shelter after the Jogjakarta earthquake. Disasters 2010, 35, 243-267. [CrossRef]

37. The World Bank. REKOMPAK: Rebuilding Indonesia's Communities after Disasters; REKOMPAK: Jakarta, Indonesia, 2012.

38. Mount Merapi volcano erupts, spews red-hot lava. The Jakarta Post, 19 February 2021.

39. Muryanto, B. Emergency status declared in Yogyakarta amid floods and landslides. The Jakarta Post, 30 November 2017.

40. Ismiyati, A.; Lestari, F. Analysis on emergency and disaster preparedness level of hospitality industry in palu and gorontalo cities. Int. J. Saf. Secur. Eng. 2020, 10, 671-677. [CrossRef]

41. BPBD North Sumatera. Performance Report of BPBD of North Sumatera Province 2019; BPBD North Sumatra: Medan, Indonesia, 2019.

42. WHO. Indonesia: Earthquake, Yogyakarta and Central Java-Emergency situation Report Number (1) 29 May 2006 (Monday); World Health Organization: Geneva, Switzerland, 2006.

43. West Java Local Government. Most Earthquake Damage in Tasikmalaya Regency. 2017. Available online: https:/ /www.jabarprov. go.id/En/index.php/news/4917/Most_Earthquake_Damage_in_Tasikmalaya_Regency (accessed on 15 September 2021).

44. The Jakarta Post. West Java landslides kill 11, injure 18. The Jakarta Post, 10 January 2021.

45. Mulyasari, F.; Inoue, S.; Prashar, S.; Isayama, K.; Basu, M.; Srivastava, N.; Shaw, R. Disaster Preparedness: Looking through the Lens of Hospitals in Japan. Int. J. Disaster Risk Sci. 2013, 4, 89-100. [CrossRef] 
46. James, E. Getting Ahead of the Next Disaster: Recent Preparedness Efforts in Indonesia. Dev. Pract. 2008, 18, 424-429. [CrossRef]

47. Zoraster, R.M. Barriers to Disaster Coordination: Health Sector Coordination in Banda Aceh Following the South Asia Tsunami. Prehosp. Disaster Med. 2006, 21, S13-S18. [CrossRef] [PubMed]

48. UNDP. 150,000 People in Quake-Hit Lombok will Benefit from New Vocational Schools and Health Facilities with UNDP's Support. 2021. Available online: https://www.id.undp.org/content/indonesia/en/home/presscenter/pressreleases/2021 /People-in-quake-hit-Lombok.html (accessed on 12 January 2022).

49. Aljazeera. 'Everything Is Broken': Healthcare after the Palu Disaster. 2018. Available online: https://www.aljazeera.com/news/ 2018/10/28/everything-is-broken-healthcare-after-the-palu-disaster (accessed on 12 January 2022).

50. Radovic, V.; Vitale, K.; Tchounwou, P.B. Health facilities safety in natural disasters: Experiences and challenges from south east Europe. Int. J. Environ. Res. Public Health 2012, 9, 1677-1686. [CrossRef] [PubMed]

51. The Ministry of Public Works and Housing. Undang-Undang Republik Indonesia Nompr 28 Tahun 2020 Tentang Bangunan Gedung; The Ministry of Public Works and Housing: Jakarta Selatan, Indonesia, 2002.

52. Presiden Republik Indonesia. Peraturan Pemerintah Nomor 16 Tahun 2021 Tentang Peraturan Pelaksanaan Undang-Undang Nomor 28 Tahun 2002 Tentang Bangunan Gedung; Pemerintah Republik Indonesia: Jakarta, Indonesia, 2021; p. 406.

53. Indonesia Investments. Massive Electricity Blackouts in Java; A look at Indonesia's Electrification Ratio \& PLN's Performance 2019. Available online: https://www.indonesia-investments.com/news/news-columns/massive-electricity-blackouts-in-java-alook-at-indonesia-s-electrification-ratio-pln-s-performance/item9179 (accessed on 12 January 2022).

54. Marlyono, S.G.; Nandi, N.; Irawan, L.Y.; Ayuni, I.K.; Sumarmi, S. Non-structural Components influencing Hospital Disaster Preparedness in Malaysia Non-structural Components influencing Hospital Disaster Preparedness in Malaysia. IOP Conf. Ser. Earth Environ. Sci. 2018, 140, 012007. [CrossRef]

55. World Bank Group. Urban Fire Regulatory Assessment \& Mitigation Evaluation Diagnostic; World Bank Group: Washington, DC, USA, 2020.

56. Lapčević, Z.; Mandić-Rajčević, S.; Lepić, M.; Jovanović, M. Evaluating a primary healthcare centre's preparedness for disasters using the hospital safety index: Lessons learned from the 2014 floods in Obrenovac, Serbia. Int. J. Disaster Risk Reduct. 2019, 34, 436-442. [CrossRef]

57. Yari, A.; Zarezadeh, Y.; Fatemi, F.; Ardalan, A.; Vahedi, S.; Yousefi-khoshsabeghe, H.; Boubakran, M.S.; Bidarpoor, F.; Motlagh M.E. Disaster Safety Assessment of Primary Healthcare Facilities: A Cross-Sectional Study in Kurdistan Province of Iran. BMC Emerg. Med. 2021, 21, 23. [CrossRef] [PubMed]

58. Heriyanto, D. Blackout in Western Java: What We Know so Far. The Jakarta Post, 2019. Available online: https://www. thejakartapost.com/news/2019/08/07/blackout-jakarta-java-outage-paralyzed.html (accessed on 11 September 2021).

59. Kahfi, K. 'Not Ordinary Rain': Worst Rainfall in over Decade Causes Massive Floods in Jakarta. The Jakarta Post, 2020. Available online: https:/ / www.thejakartapost.com/news/2020/01/01/not-ordinary-rain-worst-rainfall-in-over-decade-causes-massivefloods-in-jakarta.html (accessed on 20 November 2020). 